\title{
The Influence of Translation on the Arabic Sentence Structure: Electronic Journalism as a Model
}

\author{
Yahya Ababneh, Rafat M. Al Rousan \\ Yarmouk University, Irbid, Jordan
}

\begin{abstract}
This study investigates the influence of translation from English on the Arabic language. Specifically, it attempts to study how the translation of English auxiliary verbs influences the syntactic structure of the Arabic sentence and how the English predicating structure affects that of Arabic. This study is qualitative in nature. The data of this study were based on the language of electronic journalism in Jordan as a model. A sample from two popular news agencies in the Jordanian electronic media was chosen. The study reveals that the translation of English auxiliary verbs has influenced the syntactic structure of the Arabic sentence. Particularly, the study indicates that the influence of the English auxiliary verb on Arabic caused the passive form to die out from the actual use of the Arabic language. The study also reveals a change in the predicating structure of the Arabic sentence. Moreover, the study shows a change in the deictic indication of some of the demonstratives used in Arabic sentence structures.
\end{abstract}

Keywords: translation, English, auxiliary verbs, Arabic sentence, electronic media

\section{Introduction}

This study investigates how translation from English influences the Arabic language. The influence of translation from English on Arabic is a significant current issue of discussion (Abdallah, 2018). The present research is related to the field of translation studies and translation of the media, in particular.

The Arabic language has been influenced by translation from other languages, particularly English, which has influenced the Arabic phonological, morphological, syntactic, and semantic levels. A number of Arabic syntactic structures have changed and new syntactic patterns have emerged due to the influence of translation, such as new auxiliary patterns, new predicating structures, and new passive structures. All of these structures were not formerly recognized in Standard Arabic (SA). However, scholars have not paid enough attention to this particular topic. It is believed that the influence of translation is only limited to the morphological and phonological levels, such as the influence of English on names of shops, foods, and languages of computer-mediated communication.

This study takes the Jordanian electronic journalism as a model. A number of scholars claim that the language of media is an under researched field, and most studies ignore the role of translation in the media (Brook, 2012). Darwish (2005) also points out that very little research has been conducted on the influence of translation from other languages on Arabic. Other scholars claim that new changes and development in Arabic may be attributed to the influence of the media (Abu-Ssaydeh, 2004). English was chosen because it is the first

Yahya Ababneh, PhD., Professor, Department of Arabic Language and Literature, Yarmouk University, Irbid, Jordan. Rafat M. Al Rousan, PhD., Assistant Professor, Department of Translation, Yarmouk University, Irbid, Jordan. 
media language in the world, and the Arabic media has been greatly influenced by it.

This study aims to investigate the influence of translation from English on the syntactic structure of Arabic. Specifically, it attempts to study the effect of translating the English auxiliary verbs on the Arabic sentence structure and to investigate whether the predicating structure of English influences that of Arabic.

The study attempts to answer the following questions: (1) How does the translation of English auxiliary verbs affect the structure of the Arabic sentence? (2) Does the English predicating structure influence that of Arabic?

\section{Background of the Study}

Human languages are divided into two main categories in terms of freedom and restriction. Firstly, free languages whose linguistic levels may be subject to drastic changes, such as English, European languages, and many other human languages. Secondly, constrained languages that resist change over time because of a sacred boundary such as Arabic, which was constrained and stabilized by the descent of The Holy Quran at a certain level of its use. This level does not allow linguistic development rules to work freely due to the existence of a principle that monitors any interference resulting from these rules. Another example is Hebrew, in which the scriptures of Torah or the so-called Old Testament were written. Even though these scriptures are not so restrictive, they are regarded as one of the factors that prevented the change of the Hebrew dialect (Abd Al-Tawaab, 1985).

There are four main levels of linguistic structure: phonological, morphological, syntactic, and semantic. The phonological level is concerned with studying the sounds of language both physically and functionally. The second level is the morphological level; it studies the structure of the word and is linked to another sub-level, which is the lexicon level. The syntactic level governs the overall structure of the sentence. This particular level is concerned with forming new syntactic rules in language and monitoring linguistic changes. The final level is the semantic level which focuses on studying the meaning of words, phrases, and sentences, and it facilitates communication among speakers of a single language.

Phonological changes exist in all human languages. However, these changes are of limited value due to the similarities between natural human languages (Ababneh \& Zoubi, 2008). However, these changes do not cause a shift in the linguistic level, which lead to the distortion of the language system. On the other hand, the morphological level in some languages such as Arabic does not undergo serious changes for many reasons, the most important of which is the cultural factor. For example, when Arabic came into contact with the languages of neighboring countries, a change occurred in a number of semantic fields, such as food, industrious products, perfumes, etc. However, this change did not seriously disrupt the morphological system of Arabic. The semantic level is also subject to great changes; however, the language does not give up its structures, as these semantic changes quickly become a semantic heritage studied within the historical semantic development.

In fact, the syntactic level is the most significant of all. A change in the syntactic structure level will result in new structures that move the language from constraint to freedom. When the difference between the new (modern) level and the standard level expands, the new level wins over the standard level that protects the cultural heritage product achieved by Arabs over the centuries.

\section{Auxiliary Words in Arabic}

Traditional Arab grammarians did not pay attention to auxiliary words in Arabic. They only concentrated on 
the limits and surface structures of the Arabic sentence. They divided speech into three parts: nouns, verbs, and particles. Every word that belongs to the category of nouns or verbs occupies an essential position in the parsing system, and it cannot be an auxiliary word whose function is similar to that of verbs to be in English or other such languages. In English, if the subject is a noun and the predicate is also a noun, there should be an auxiliary verb occupying the middle position (Gelderen, 2010). This structure does not exist in Arabic or any other Semitic language (Ababneh, 2018).

Noteworthy is that traditional Arab grammarians had knowledge about the auxiliary words, but this knowledge did not lead to grammatization. They defined, for example, the function of اي ay (o') used with a male and اية أيها و. الرجلya: ?ayyuha arajalu (O’ man), and بي أيتها المرأةya: ?ayytuha almar?ah (O'woman), as an auxiliary word. However, they looked at the structure in which these helping words were used a far cry from this topic because they were classified as names. For them, these words must occupy a parsing position because they are not auxiliary words from a syntactic perspective, but they are so from a phonological and a semantic perspective (Al-Suyuuti, 1977). Syntactically, they occupy a vocative position, according to the Arabic predicating relations. Here, we point out these auxiliary words are non-pivotal functional terms in semantics, and that Arabic structural system may or may not permit their existence.

The notion of auxiliary verbs was first introduced at the conference of the former Arabic Language Academy, claiming that verbs to be in Arabic are auxiliary verbs. In contrast, this study claims that verbs to be in Arabic are not auxiliary verbs at all because they serve a temporal function. For example, one poet said:

فكيف اذا مررث بدار قوم وجيران لنا كانوا كرام kira:mu (What if I pass by a home of people who were our neighbors and were noble and dignified) (Al-Zujaji,

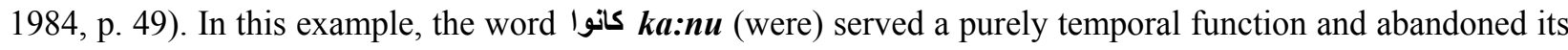
role in the sentence structure and the predicating relations. Therefore, it is not an auxiliary word. That said, the idea of auxiliary words does not exist in Arabic except in أيay (O') ayyat (O'), and there is no way to talk about their presence in Arabic by comparing them to their counterparts in English, for the systems of the two languages are different.

However, the modern standard level of Arabic has been influenced by the English language system. This suggests that the syntactic level of Arabic has begun to deviate from the original norm of Standard Arabic. This study presents some examples used by Arabic writers and specialists.

\section{Auxiliary Verbs in English}

In general, verbs in English are divided into two main types: lexical verbs and auxiliary verbs. Lexical verbs are the basic full verbs, and they carry their own meaning. They denote an action taking place in a sentence, and they provide the main semantic content of the clause. Auxiliary verbs or helping verbs, on the other hand, add more functional or grammatical meaning to the clauses in which they are used. They help another verb in the sentence, but they do not contribute greatly to the meaning of the clause. Auxiliary verbs are used to show the tense, voice, aspect, emphasis, or mood (Quirk, 1973). They have different types and functions, and they are basically two types: primary verbs including: be, have, and do, and modal verbs including: will, would, can, could, shall, should, may, might, must, had to. Some of these modals are called marginal auxiliary verbs, such as need, dare used to, and ought to (Quirk, 1973). Tend to and had better, which are called semi-auxiliaries, serve the same syntactic function as the modals in English, which are nonexistent in Arabic. 
Moreover, auxiliary verbs such as have, be, and do in English can be used as lexical (main) verbs or auxiliaries (Gelderen, 2010). In (1a), have is a lexical verb; it means "to possess" and occurs alone without another verb. In (1b), however, have does not mean "to possess" or "to hold", but contributes to the grammatical meaning of the sentence, namely past tense with present relevance. Therefore, it is used as an auxiliary to the lexical verb lived. Similarly, in (2a), the auxiliary verb be is the only verb used in the sentence, and therefore, it is lexical. On the other hand, be is used in (2b) as an auxiliary that contributes to the grammatical meaning to emphasize the progressive nature of the action. The same is true for the verb do as given in (3a) and (3b).

(1) a. I have a car.

b. I have lived here for 10 years.

(2) a. That man is a teacher.

b. That man is working too hard.

(3) a. He did his homework.

b. She did not go to work last night.

Auxiliaries cannot occur alone, except when they are main verbs (Gelderen, 2010), as in (1a), (2a), and (3a) because they help other verbs. Thus, (4) below is ungrammatical:

(4) *I can English.

The auxiliary be can distinguish from all other auxiliary verbs in that it comes with the conjugated verb having the enclitic (-ing) as in (5) below:

(5) They are eating their lunch.

\section{Review of Literature}

Traditional Arab scholars paid attention to the danger of transformations on the syntactic level of Arabic, and therefore, tried very hard to save it from change. Therefore, a number of them studied such transformations in a collection of research papers which they called the "Books of Grammatical Errors by the Public". These studies began at an early stage in the life of Arabic authorship, such as Al-Kisaa'i (189 Hijra Year), Al-Sagli (501 Hijra Year), Ibn Al-Jawzi (597 Hijra Year), and Al-Safadi (501 Hejra Year) (source). The focus of these studies was mainly on aspects of variation between the Standard Arabic and the Arabic dialects. Particularly, they studied the morphological aspect of Arabic and rarely paid attention to structural transformations. In fact, these past studies represent a departure from the structural norm after they were in conformity with it.

Similarly, modern studies have not been different from the old ones in their interest in the morphological aspect; only few of them have dealt with some forms of structural change. For example, Al-Zoubi (2006) investigated the forms of syntactic transformation in the language of short stories in Jordan in the 1970s and 1980s. Al-Jabaali (2004) also discussed the impact of globalization on the linguistic structures of the language of short stories in Jordan after the age of globalization. Moreover, there was a report published by Majma3 ?al-lughah ?al-3arabyiah (2014) (The Academy of Arabic) on the image of the Arabic language in the media. It was a detailed report focusing on spelling, morphological and structural errors, and weak language editing in the media. This report was primarily concerned with linguistic editing and language mistakes and paid limited attention to the new structures of Standard Arabic. However, it produced many useful recommendations.

Abdalla (2018) studied the influence of translation from English on Arabic with a focus on the translation. The influence of media language was confirmed in his study. Abdallah indicated that journalists should be careful not to distort the structure of the Arabic sentence when translating idioms from English. It is important to mention 
that these studies were not interested in the elements of predication except in terms of the existence of the standard errors. Therefore, the present study concerns itself with the emergence of a new syntactic level of Arabic that did not exist in Standard Arabic, the auxiliary verbs, which resulted from the influence of translation from English.

\section{Research Data}

The data of this study were based on the language of electronic journalism in Jordan as a model, in which the patterns affected by the translation from English were especially investigated. A random sample was selected from two popular news sites in the Jordanian electronic press, which are primarily concerned with news publishing and news analysis, namely: "Saraya News Agency" and "Ammon News Agency", between 01/04/2018 and 01/10/2018. These two news agencies receive their material from the Jordanian News Agency. They were also among the news agencies whose editing problems were investigated by the Media Monitoring Committee formed by the Jordanian Academy for Arabic Language 2011.

\section{Discussion}

Translating auxiliary verbs from English into Arabic has influenced the structure of the Arabic sentence in many ways, the most important of which are the following: (1) change in the predicating structure; (2) the loss of deictic indication of demonstratives; and (3) the emergence of auxiliary verbs.

\section{Change in the Predicating Structure}

The predicating structure is one of the most important structures of the Arabic syntactic system. Arabic defines two types of predication in its sentential system, namely: Nominal Predication and Verbal Predication.

In the first type, the predicating relationship occurs between a subject (noun) and a predicate (noun) that do not accept a verb as a basic element in its structure, whereas the predicating structure in the second type is based on the relationship between a subject (noun) and a predicate (verb) (Ababneh, 2017). Based on this, Arab syntacticians categorize the Arabic sentence into two types: Nominal Sentence and Verbal Sentence. The subject musnad ?ilaih in both types must be a noun. However, the predicate musnad is different in both types. Whereas the predicate is a noun in the case of a nominal sentence as in (6), it must be a verb in the case of a verbal sentence as in (7).

(6) الجو بارد. (7)aljawu ba:ridun (The weather is cold).

(7) akala lwaladu tufaHata (The boy ate the apple).

Unlike Arabic sentences, all English sentences are verbal even though every sentence is made up of a subject and a predicate. Subjects and predicates are the main components of the English sentence. They contain the most essential information of every sentence. In example (8) below, the word dogs is the subject of the sentence, whereas the phrase are animals is the predicate.

(8) Dogs are animals.

The second main element of the English sentence is the verb, which is either lexical or auxiliary as mentioned before.

We can say that the effect of translation finds its way into the structures of the Arabic sentences, which are incompatible with their counterparts in English, by effecting the "subject" ?almusnad ?ilaih in the Arabic sentence. Therefore, a translator, who is not competent in both systems, subconsciously begins the Arabic sentence with a noun not a verb when translating from English to Arabic. This greatly contributes to the loss of some uses of the verbal sentence in favor of the nominal sentence in Arabic. For example, 


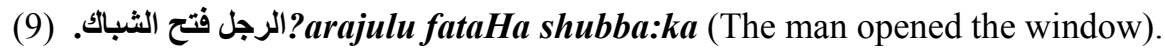

(10) الولا ركل الكرة. alwaladu rakala lkurata(The boy kicked the ball).

Even though the nominal structures in (9) and (10) are grammatical in Arabic, it is preferable to use the verbal structure as in (11) and (12), the structure that begins with the verb (predicate), for two reasons. The first one is that the verbal sentence is a dynamic structure that suggests movement and interaction. Secondly, if the nominal structure persists, the verbal sentence will be neglected in favor of the nominal sentence.

fataHa arajulushubba:ka (The man opened the window).

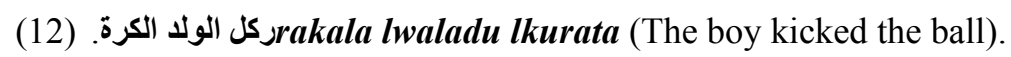

The researchers do not claim that the nominal structure is always unfavorable, but we say that, nowadays, it is remarkably used in Arabic to a degree it became the dominant form of modern sentence structures. This is indeed attributed to the influence of translation from English into Arabic.

\section{The Loss of Deictic Indication of Demonstratives in Arabic}

The influence of translation from English to Arabic gave rise to a new type of sentences that begin with an indefinite noun, which is deemed ungrammatical in Arabic, or sentences that begin with a place dixies such as هناك huna:ka (there), which is empty of its deictic indication as in the translation of the English phrase "There is a boy" (Lit. يوجد ولد). However, some translators interpret the meaning of the deictic expression "there" as هناك ولد any deictic indication to place or time. This new type of sentences, which did not previously exist in the Arabic syntax, can now be found even in the writings of prominent scholars in Modern Arabic, who reached a point of logical contradiction, as Mahmoud (n.d.) said: "أمن المكن ان يكون هناك ضبع بالقرب مني؟"?amina Imumkini ?an yaku:na huna:ka Dab3un bilqurbi minni (Is it possible that there is a hyena near me). Thus, the contradiction lies in the use of هilhuna:ka (there) since it is a deictic expression pointing to an object distant from the speaker (Abd Al-Ghani, 1982); however, in this sentence, it is used to point to an object that is distant-near the speaker (Al-Zoubi, 2006). This contradiction stems from the fact that the writer was influenced by the journalistic style resulting from the imprudent translation of the English sentence "Is it possible that there is a hyena near me?" The Standard Arabic predicating structure, however, requires that the sentence be "من المكن أنَّه يوجد ضبع بالقرب? "مني?"?amina Imumkini ?annahu yu:jadu Dab3un bilqurbi minni.

Whatever the case is, expressions, such as هناك فرق بين كذا وكذا hinana:ka farqun bayna kadha wa kadha (There is a difference between such and such), and هناك علم بالأمر وكن huna:ka 3ilmunbil?amri (There is knowledge of the matter), are structures that became widely used by translators first, and were then adopted by journalists and scholars in different fields of science. It is worth pointing here that the Arabic syntax allows a speaker to begin a sentence with an indefinite noun, provided that the predicate is fronted obligatorily, and it is considered an additive or prepositional phrase, such as غندنا كتاب 3indana kita:bun (We have a book) or في بيتا كتاب fi baytina kita:bun (There is a book in our house) (Al-Ansaari, 1985). We should not empty the demonstrative pronoun هishuna:ka from its adverbial meaning as well as its intrinsic deictic indication pointing to time and place.

\section{The Emergence of Auxiliary Verbs in Arabic}

The study observed a number of auxiliary verbs in Modern Standard Arabic, including: تَtamma (be completed), جقامqa:ma (be performed), جرى أخذ ?axa (be conducted), and (be started). These auxiliary verbs vary in terms of degree of use. They all share the fact that they are all new to the Arabic language due to the influence of translation from English. 


\section{The Verb ت̈tamma (Be Completed)}

The verb "̈tamma is not a newly derived verb in the Arabic language. It is a full lexical action verb associated with the time it is used to indicate, whether past تَّamma, present yatimu, or future yatimu. Ibn Mandhour (1955) defines it as perfect, the opposite of imperfect. Presently, it is used as an auxiliary in the language of the media, the language of academic writing, and even in the writings of Arabic specialists. The basic features of this verb were eliminated in MSA. It was completely stripped off from its action and temporal signification and used only as an auxiliary verb, especially when associated with a verbal noun. Consider examples (13) and (14) below.

تمُّ استعمال الكتاب (13)tamma isti3ma:lu lkita:ba (The book was used).

تيّة استعمال الطالب الكتاب أو للكتاب (14tamma isti3ma:lu Ta:liba alkita:ba aw lilkita:bi (The book was used by the student).

Although the two previous examples seem similar, it is not quite the case. They will be discussed in the following paragraphs.

It is already mentioned that Arabic in its standard form accepted some auxiliary patterns that are not originally considered auxiliary verbs. This study calls them auxiliary words in order not to mix them with the term "auxiliary verb" used in English. In fact, Arabic syntacticians refused to conceive them as auxiliary words. Instead, they insisted that they must be treated as full lexical verbs although they are free from lexical and derivational content, such as the vocative particle يlayy and ايةayyat. Nevertheless, MSA, which is nowadays used by translators, media, and even some of those specialized in Arabic, who have been influenced by translation or the media, allows the use of specific words that are certainly the result of translation from other languages, such as the verb ت̈tamma in (13) and (14). In the previous examples, the verb ت̈tamma has been used as an auxiliary verb.

Now, the differences between (13) and (14) will be discussed to reveal the effect of translation on the predicating relations.

In example (13) above, the verb ت̈tamma is considered a complete action verb from an educational point of view. In this structure, it does not represent any action value, from which an event or an action can be understood to have happened or attributed to any subject musnad ?ilaih. It is, in fact, an auxiliary element, which means nothing more than what the genitive, استعمال? ?isti3ma:l (use) means. As for its function, it is a verb that does not have a subject; in other words, it is a predicate musnad having no subject musnad ?ilaih because the verbal noun استعمال?isti3 mal is not capable of performing any action. The reason for the tendency of this structure is to get rid

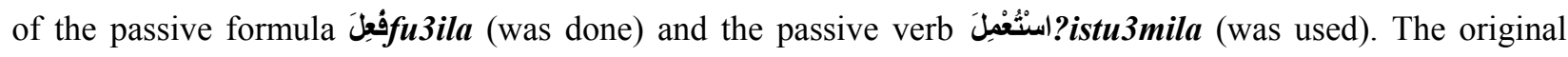
Standard Arabic structure for this example is استُعْمِل الكتاب (سistu3mila lkita:bu, in the passive form. We believe that there is no need to use the auxiliary verb ت̈tamma, which lacks the essential characteristics of a full lexical verb. Now, we will discuss structure (14).

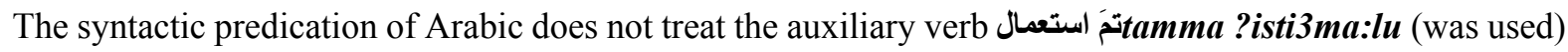
as a passive form as in (13) although it is identical with the passive form استُعْمِن considered an active form, so we say: ستعمال الطالب الكتاب:isti3ma:lu ?aTaalibu lkitaaba because the genitive in the structure ستعمال الطالب?isti3ma:lu aTa:libu (the student's use) is the subject (i.e., the doer of the action), and this requires a distinction between the two structures in the process of reverse translation, where the first is a passive structure and the second is an active one. 


\section{The Verb (قام)qa:ma}

In Arabic lexicons, the verb قäqama has more than one lexical meaning carrying action and time significations, the most important of which is "standing", the opposite of "sitting" (Ibn Mandhour, 1955, p. 496). Another meaning is "determination" as in the Quranic verse وانه لما قام عبدالله يدعوه (Quran, 72:19) (And when the servant of Allah stood up to invoke him). It also has the meaning of "protection and reform" as in the following Quranic verse "'الرجال قوامون على النساء بما فضل الله بعضه عن بعض (Quran, 4:34) (Men are the protectors and maintainers of women because Allah has given the one more strength than the other) and in the verse "إلا ما دمت عليه قائماً" (Quran, 3:75) (unless you constantly stand demanding).

On the other hand, Al Zamakhshari (1982) indicates that the verb aقام qa:ma also has a metaphorical meaning that does not affect its structural function. For example, when we say: بكم قام عليك المتاع bikam qa:ma 3alaika lmata:3 (How much did the belongings cost you), ققام عليَّ بالعمل qa:ma 3alyun bil3amali (Ali did the work), قاد بعيرك مائة دينار (Your camel is worth 100 Dinars), and so on.

The verb بقام qa:ma in the above examples is a full verb that carries both core intrinsic denotations: time and action. However, it was stripped off from these two denotations in the modern use. Thus, the verb aقامa:ma and its present form yaquum come in the second place among the actual auxiliary patterns, a use that strips it off from action and time signification. For example,

(15) قِامت السلطة باستنجار 26 بئراً خاصاً (Ta:mat iSultaltu bisti?ja:ri 26 bi?ran xa:San (The authority rented 26 special wells).

This is the modern use of the verb قa:ma; it is used as an auxiliary verb. This sentence means exactly the same as,

(16) ?ista?jarat ?aSulTatu 26 bi?ran Xa:san (The authority rented 26 special wells). It is the standard form of the sentence.

(17) أن يقوم بردِّ كافة القوانين المؤقتّة (Tan yaqu:ma biraddi ka:fati lqawa:ni:ni Imu?qatati (To reject all provisional laws). It means the same as in (18).

(18) أن يردَّ كافة القوانين الموقته. (Tan yarudda ka:fati lqawani:ni lmu?qatati (To reject all provisional laws).

The former sentence is the modern use, whereas the latter is the standard use.

The verb قäqa:ma is similar to the verb تّtamma when they are used as auxiliaries, where both become empty of action and time indications, so there is no difference between the past form and the present form with regards to time significance. The structures in (15), (16) and (17), (18) have become interchangeable without affecting the action and time since the verb قa $q a: m a$ is used as an auxiliary, and thus, unnecessary.

\section{The Verb (جرى) Jara}

According to Arabic lexicons like lisa:n ?al/arab, the verb جرajara is derived from the state of jarayan (Ibn Mandhour, 1955, V. 14, pp. 140-141), meaning "running" (e.g., running water/running ship), "moving" (e.g., moving ship), or "flowing" (e.g., flowing river). It was borrowed to express the case endings of uninflected and inflected speech and the case ending of the rhyming sounds in prosody. It was also borrowed to express sustainability and permanence of the action. For example, جرى له ذلك الثي؟ jara lahu dha:lika šai?, meaning "lasted" (Ibn Mandhour, 1955, V. 14, pp. 140-141). However, to assign the verb جرئ دجرى to strip it off from its action and time signification is something new to the Standard Arabic language. For Example, 
(19)زجرى بحث كافة الأمور المتعلّقة بالأوضاع الراهنة (jara baHthu ka:fati l?umu:ri lmu3aliqati bil?awDa:3i ra:hinati (All issues related to the current situation were discussed), meaning that,

buُشِثَ الأمور المتعلّقة بالأوضاع الراهنة. (20)Hithat ka:fati l?umu:ri lmuta3aliqati bil?awDa:3i rahinati, which translates to the same thing as the former sentence.

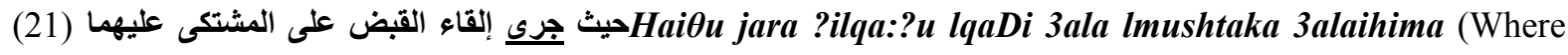
both defendants were arrested), means the same as:

(22) ألقِيَالقبض على المشتكى عليهما (ulqiya lqabDu 3ala lmushtaka 3alaihima.

It is worth noting that although the structures in (19) and (22) are in the active voice, where the verb جزara in them both do not denote any time or event, and the structures in (20) and (22) are in the passive voice and do not contain the verb جرى jara, and they both have the same exact meaning. The verb جزara in the abovementioned examples was mainly used to eliminate the passive structure of Standard Arabic.

\section{The Verb أخذ(?axadha) (Be Started)}

This verb أخذ?axadha is one of the verbs of "beginning” (Khalil, 2010). However, in the following examples, it is used as an auxiliary verb that does not denote time or action. This verb is the least frequently used auxiliary compared to the previously discussed ones. Consider the following examples taken from the data.

خاصة أنَّ حالات الاعتداء أخذت بالزيادة (28a:Satan ?anna Ha:lati l?i3tida:? ?axadhat bilzia:dati (Especially that assault cases increased), meaning the same as the standard structure:

(29xa:Satan ?anna Ha:lati l?i3tida:? za:dat.

The effect of this verb in eliminating the active verb form is clear, especially from its indication of time and action.

\section{Conclusion}

The Arabic syntactic rules are largely fixed based on the criterion of linguistic constraint. That is why Arabic is one of the constrained languages that are not free to maneuver in their structural level. Therefore, Arabic has stood its ground and maintained that there is no justification for the existence of auxiliary verbs, such as those found in English, for example. However, in the modern era, Arabic has begun to develop auxiliary verbs such as

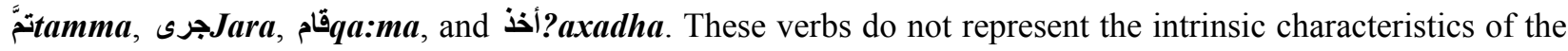
verb: action and time. They exist in their actual Arabic lexical form, but their use as auxiliary verbs is a recent one, resulting from the effect of translation. This significant linguistic development has led to noticeable changes in the syntactic system of the Arabic sentence, such as the following:

-Change in the deictic indication of some of the demonstratives which were used in the predicating relations, as they do not point to anything and do not carry a deictic indication.

-The loss of some actual verbal sentence patterns, such as:

هوجد فرق farq (There is a difference), which has exactly the same proposition, as a result of translation.

-The influence of the English auxiliary verb on the Arabic language system caused the passive form of the verb فُ fusila to die out from the actual use of the Arabic language.

-In addition to the loss in the passive form of the verb rhyming with $\mathbf{f u 3 i l a}$, a large number of active forms have also disappeared, a loss that will seriously affect the Arabic sentence structure. 
Finally, this study provides an insight about a new movement in Modern Arabic to form a new structure that did not originally exist in Standard Arabic, the formation of auxiliary verbs that do not denote the time and/or the action of the verb. This, in turn, contributes to the creation of a new structural level in the Arabic syntax that can be avoided if the normative standard form of Arabic is taken into account.

\section{References}

Ababneh, Y. (2017). ?al-taHli:li:nadhara:t mu3a:Sirah (Analytical Arabic syntax: Contemporary perspectives). Irbid: Dar Al-Kitaab Al-Thaqaafi.

Ababneh, Y. (2018). ?al-naHw ?al-3arabi ?al-muqa:ranf Fi dhu:??al-lugha:t ?al-sa:myiahwa l-lahajaat ?al-3arabyyiah ?al-qadi:mah (A comparative Arabic grammar in light of the Semitic languages and ancient Arabic dialects). Irbid: Dar Al-Kitaab Al-Thaqaafi.

Ababneh, Y., \& Al-Zoubi, A. (2008). 3ilm ?al-lughah ?al-mu3a:Sir: Mugadima:t wa taTbi:qa:t (Contemporary linguistics: Introductions and applications). Irbid: Dar Al-Kitaab Al-Thaqaafi.

Abdallah, M. S. (2018). The influence of translation on the Arabic language. UK: Cambridge Scholars Publishing.

Abd Al-Ghani, A. (1982). Mu3jam ?al-nahw (The lexicon of syntax). Beirut: Al-Sharikah Al-MutaHidah liltawzee3.

Abd Al-Tawaab, R. (1985). Fi qawa3id ?al-Sa:myia:t: ?al-3ibriyiahwa l-syrya:nyiahwa l-Habashyiah:ma3?al-nusu:swa l-mufarqa:t (The grammar of Semitic languages: Hebrew, Syriac and Habashite: With texts and comparisons). Cairo, Egypt: Maktabat Al- Khanji.

Abu Ssaydeh, A. (2004). Translation of English idioms into Arabic. Retrieved on July 6th, 2019 from https://www.researchgate.net/publication/233620439_Translation_of_English_idioms_into_Arabic

Al-Ansaari, I. H. (1985). Mughni ?al-Labi:b 3anKutub il-?a3areeb. Investigated by M. Al-Mubarak and M. Hamdallah. Beirut: Dar Al-Fikr.

Al-Jabaali, Y. (2004). The effect of globalization on the linguistic structure of the language of short story in Jordan (Unpublished MA thesis, Yarmouk University).

Al-Suyuuti, J. (1977). Hama3?al-hawami3 Fi Sharh Al-Jawami3 (Shedding tears while explaining collections). Investigated by M. Abdul3a:1. Kuwait: Dar Al-Buhu:th Al-3ilmyyiah.

Al-Zamakhshari, A. Q. (1982). ?asas ?al-Bala:ghah (The basis of rhetoric). Investigated by M. Abdulraheem. Beirut: Dar Al-Ma3rifah.

Al-Zoubi, A. (2006). Fi tahawul ?al-?asali:b ?al-nahwiyyah fi ?al-3agdayn ?al-sa:bigayn 3ala MarHalat ?al-3awlamah (The transformation of syntactic methods in the two decades preceding the globalization phase). Majalat Jami3at Damasus, 22(1), 2.

Al-Zujaji, A. Q. (1984). ?al-Jumal fi l-nahw (Sentences in syntax). Irbid: Dar Al-Amal.

Aziz, Y. (1994). Maba:di??al-tarjamahm min ?al-Injli:zyiah ?ila ?al-3arabyiah (The principles of translation from English to Arabic). Musil, Iraq: Manshu:ra:t Ja:mi3at Al-Mu:sil.

Brook, J. (2012). The role of translation in the production of international print news: Three case studies in the language direction Spanish to English (Doctoral dissertation, ResearchSpace@Auckland).

Darwish, A. (2005). Language, translation and identity in the age of the internet, satellite television and directed media. Melbourne: Writescope.

Gelderen, E. V. (2010). An introduction to the grammar of English. Amsterdam, Philadelphia: John Benjamin Publishing Company.

Hibbo, A. (1990). ?al-madkhalila?alughah ?al-syrya:niyah (An introduction to the Syriac language). Damascus: Dar Al-Kitaab.

Ibn Mandhour. (1955). Lisa:n ?al-3arab (The Arab tongue). Beirut: Dar Saadir.

Khalil, A. (2010). A contrastive grammar of Arabic and English (2nd ed.). Amman: Jordan Book Center.

Majma3 ?al-lughah ?al- 3arabyiah. (2014). Su:rat ?al-lughah ?al- 3arabyyiah fi wasa:?il ?al-?i3la:m wa l-?itiSa:l (The image of Arabic in media and means of communication). Manshu:rat ?al-lajnah ?al-watanyyiah Lilnuhu:D bi Lughah ?al-3arabyyiah bi 1-majma3.

Mahmoud, F. (n.d.). ?al-3ubu:r du:na jadwa (majmu:3ah qaSaSyiah). (Crossing without success (a story collection). Amman: Philadelphia Publication House.

Quirk, R. S. (1973). University grammar of English. London: Longman.

The Holy Quran. 